\section{Effect of Dietary Phosphorus on Circulating Concentrations of 1,25-Dihydroxyvitamin D and Immunoreactive Parathyroid Hormone in Children with Moderate Renal Insufficiency}

Anthony A. Portale, Beverley E. Booth, Bernard P. Halloran, and R. Curtis Morris, Jr. General and Pediatric Clinical Research Centers, Departments of Pediatrics and Medicine, University of California at San Francisco, California 94143 bstract. The hyperparathyroidism characteristic of patients with moderate renal insufficiency could be caused by decreases in the plasma concentration of ionized calcium $\left(\mathrm{Ca}^{++}\right)$evoked by: $(a)$ recurring increases in the plasma concentration of inorganic phosphorus that may be detectable only in the post-prandial period; $(b)$ a reversible, phosphorus-mediated suppression of renal 25-hydroxyvitamin D-1 $\alpha$-hydroxylase that decreases the plasma concentration of 1,25-dihydroxyvitamin $\mathrm{D}(1,25$ $\left.(\mathrm{OH})_{2} \mathrm{D}\right)$ enough to decrease both gut absorption and bone resorption of $\mathrm{Ca}^{++} ;(c)$ both of these. In a group of eight children with moderate renal insufficiency, mean glomerular filtration rate (GFR) $45 \pm 4$ (SE) $\mathrm{ml} / \mathrm{min}$ per $1.73 \mathrm{M}^{2}$, ages 6-17 yr, we tested these hypotheses by determining the effect of short term $(5 \mathrm{~d})$ restriction and supplementation of dietary intake of phosphorus on the plasma concentration of $1,25-(\mathrm{OH})_{2} \mathrm{D}$, the serum concentrations of immunoreactive parathyroid hormone (iPTH) and phosphorus, and the fractional renal excretion of phosphorus (FEPi). When dietary phosphorus was normal, $1.2 \mathrm{~g} / \mathrm{d}$, the serum concentrations of phosphorus throughout the day were not greater than those of normal control children, and the serum concentrations of car-

This paper has been reported in part to the American Society of Nephrology, to the Fifth International Workshop on Vitamin D, and to the American Society for Clinical Investigation. Address reprint requests to Dr. Portale at 1202 Moffitt Hospital, University of California at San Francisco.

Received for publication 21 December 1982 and in revised form 7 February 1984.

J. Clin. Invest.

(c) The American Society for Clinical Investigation, Inc. $0021-9738 / 84 / 06 / 1580 / 10 \quad \$ 1.00$

Volume 73 , June $1984,1580-1589$ boxyl-terminal iPTH (C-iPTH) were greater, 59 \pm 9 vs. $17 \pm 3 \mu \mathrm{leq} / \mathrm{ml}$, and unchanging; the serum concentration of intact-iPTH was also greater, $198 \pm 14$ vs. $119 \pm 8 \mathrm{pg} /$ $\mathrm{ml}$. The plasma concentration of $1,25-(\mathrm{OH})_{2} \mathrm{D}$ was lower than that of age-matched controls, $27 \pm 3$ vs. $36 \pm 2 \mathrm{pg} / \mathrm{ml}$ $(P<0.01)$. When dietary phosphorus was restricted to $0.35 \mathrm{~g} / \mathrm{d}$, the plasma concentration of $1,25-(\mathrm{OH})_{2} \mathrm{D}$ increased by $60 \%$ to a mean value not different from that of normal controls, while serum concentrations of CiPTH and intact-iPTH decreased by $25 \%$, the latter concentration to a mean value not different from that of controls. FEPi decreased from 31 to $9 \%$. When dietary phosphorus was supplemented to $2.4 \mathrm{~g} / \mathrm{d}$, the plasma concentration of $1,25-(\mathrm{OH})_{2} \mathrm{D}$ decreased $32 \%$, while those of C-iPTH and intact-iPTH increased by 131 and $45 \%$, respectively; FEPi increased from 27 to 53\%. Plasma concentrations of 25-hydroxyvitamin $\mathrm{D}$ remained normal and unchanged, and GFR did not change when dietary phosphorus was manipulated.

The data demonstrate that in children with moderate renal insufficiency: (a) A normal dietary intake of phosphorus is attended by a decreased circulating concentration of $1,25-(\mathrm{OH})_{2} \mathrm{D}$ and an increased concentration of iPTH, but not by recurring increases in the serum concentration of phosphorus at any time of the day; $(b) \mathrm{Di}$ etary phosphorus is, however, a major determinant of the circulating concentrations of both $1,25-(\mathrm{OH})_{2} \mathrm{D}$ and iPTH, which vary inversely and directly, respectively, with dietary intake of phosphorus, and increase and decrease, respectively, to normal values when phosphorus is restricted for $5 \mathrm{~d}$; (c) Restriction and supplementation of dietary phosphorus induces changes in the serum concentration of iPTH that correlate strongly but inversely with those induced in the plasma concentration of 1,25 - 
$(\mathrm{OH})_{2} \mathrm{D}(r=-0.88, P<0.001)$; and $(d)$ The physiologic responsiveness of the renal tubule to changes in dietary phosphorus is to a substantial extent intact. The data provide support for the second hypothesis stated.

\section{Introduction}

1,25-dihydroxyvitamin $\mathrm{D}_{3}\left(1,25-(\mathrm{OH})_{2} \mathrm{D}_{3}\right)^{1}$ is the metabolite of vitamin $\mathrm{D}$ currently considered to be the most biologically active with respect to bone resorption and intestinal absorption of calcium and phosphorus (1-4). The synthesis of $1,25-(\mathrm{OH})_{2} \mathrm{D}_{3}$ from its endogenous precursor, 25-hydroxyvitamin $D_{3}$, occurs in mitochondria of the proximal renal tubule and is catalyzed by the enzyme, 25-hydroxyvitamin $\mathrm{D}_{3}-1 \alpha$-hydroxylase (1-hydroxylase) (5-11). In patients with severe and moderate renal insufficiency, the occurrence of severe (12-23) and moderate $(18-24)$ reductions in the plasma concentration of $1,25-(\mathrm{OH})_{2} \mathrm{D}$ presumably reflects a reduction in the renal synthesis of this hormone $(25,26)$. In patients or animals with renal insufficiency, such a reduction could reflect a reduced amount of 1-hydroxylase, but could also reflect a reversible suppression of the activity of the remaining enzyme (27-30), even though the activity of this enzyme is normally stimulated by parathyroid hormone (PTH) (31-33), and the circulating level of this hormone is characteristically increased in these patients $(21,22,34-37)$. In some circumstances, the activity of 1-hydroxylase and apparent production of $1,25-(\mathrm{OH})_{2} \mathrm{D}$ are not principally determined by PTH, but rather by a suppressive effect of inorganic phosphorus (38-44). In patients with either idiopathic hypercalciuria (43) or primary hyperparathyroidism (44) in whom dietary phosphorus was supplemented, the circulating concentration of $1,25-$ $(\mathrm{OH})_{2} \mathrm{D}$ decreased to normal levels even though the serum concentration of immunoreactive PTH (iPTH) increased, and that of phosphorus remained normal and unchanged (43), or it decreased (44). Accordingly, in patients with moderate renal insufficiency in whom the dietary intake and serum concentration of phosphorus are not increased, but in whom the amount of phosphorus processed by the remaining nephrons is greatly increased, a phosphorus-mediated suppression of the activity of 1-hydroxylase might reduce the renal synthesis and hence the plasma concentration of $1,25-(\mathrm{OH})_{2} \mathrm{D}$, and thereby contribute to the pathogenesis of the hyperparathyroidism of these patients (21). We report a positive test of this hypothesis in children with moderate renal insufficiency: short term ( $5 \mathrm{~d})$ restriction and supplementation of dietary phosphorus induced an increase and a further decrease, respectively, in the plasma concentration of $1,25-(\mathrm{OH})_{2} \mathrm{D}$, and induced a decrease and further increase, respectively, in the serum concentration of iPTH. With restric-

1. Abbreviations used in this paper: $\mathrm{C}-\mathrm{iPTH}$, carboxyl-terminal iPTH: 1,25- $(\mathrm{OH})_{2} \mathrm{D}_{3}, 1,25$-dihydroxyvitamin $\mathrm{D}_{3}$; FEPi, fractional renal excretion of phosphorus; GFR, glomerular filtration rate; 25-OHD, 25hydroxyvitamin D; 1-hydroxylase, 25-hydroxyvitamin $D_{3}$-1 $\alpha$-hydroxylase; iPTH, immunoreactive parathyroid hormone; PTH, parathyroid hormone. tion of dietary phosphorus, the circulating concentrations of both $1,25-(\mathrm{OH})_{2} \mathrm{D}$ and iPTH became normal.

\section{Methods}

All studies were performed under a protocol approved for use by the Committee on Human Research, University of California at San Francisco. Informed consent was obtained from the parents of all children studied.

\section{Subjects}

We studied eight children with moderate renal insufficiency (glomerular filtration rate [GFR] of $\sim 25$ to $\sim 50 \mathrm{ml} / \mathrm{min}$ per $1.73 \mathrm{M}^{2}$ ) who ranged in age from 6 to $17 \mathrm{yr}$. Six of the eight children had principally tubulointerstitial renal disease, and two had principally glomerular disease. No child had received phosphorus binding agents, supplements of calcium, or, in seven of the children, supplements of vitamin D or any of its analogues. One child had received oral $1,25-(\mathrm{OH})_{2} \mathrm{D}_{3}$ (Rocaltrol, Roche Labs), but not during the 4-wk period before the study. The GFR estimated by clearance of iothalamate ranged from 27 to $52 \mathrm{ml} / \mathrm{min}$ per $1.73 \mathrm{M}^{2}$ in seven of the eight children; in one child the value was 67 , and the mean value for all was 45 .

We also studied 17 healthy children who ranged in age from 6 to $16 \mathrm{yr}$. These children had no history of renal, hepatic, or gastrointestinal disease. Four of these children were healthy siblings of the studied patients, one a cousin. Except where otherwise stated, blood was obtained from these subjects in the morning before breakfast.

\section{Procedures}

To determine the effect of a normal, then restricted or supplemented dietary intake of phosphorus on the plasma concentration of $1,25-(\mathrm{OH})_{2} \mathrm{D}$ and on the serum concentrations of phosphorus and $\mathrm{PTTH}, 13$ paired studies were performed in the Pediatric Clinical Research Center in the eight children with moderate renal insufficiency. Each child received a constant whole food diet that provided $1,000 \mathrm{mg}$ of calcium and 1,200 $\mathrm{mg}$ of phosphorus per day for $3 \mathrm{~d}$ (control period). The intake of phosphorus was then either reduced $(350 \mathrm{mg} / \mathrm{d}$, seven patients) or increased $(2,400 \mathrm{mg} / \mathrm{d}$, six patients) for $5 \mathrm{~d}$ (experimental period). Both maneuvers were carried out in five of the eight children; phosphorus restriction was studied first, while phosphorus supplementation was examined in separate studies 2 mo to 2 yr later. Phosphorus was only restricted in two of the eight children and was only supplemented in one. During the reduced intake of phosphorus, aluminum hydroxide was administered to decrease intestinal absorption of phosphorus, and calcium carbonate was administered to maintain constant intake of calcium. During the increased intake of phosphorus, the control diet was supplemented with Fleet's Phosphasoda (129 mg phosphorus per milliliter) given in 3-ml dosages by mouth with each meal. Blood was drawn daily in the morning before breakfast for measurement of serum concentrations of creatinine, calcium, phosphorus, and magnesium. At the end of the control and experimental periods (days 4 and 9), additional blood was obtained for measurement of serum concentrations of $\mathrm{iPTH}$ and plasma concentrations of 25 -hydroxyvitamin $\mathrm{D}(25-\mathrm{OHD})$ and $1,25-(\mathrm{OH})_{2} \mathrm{D}$. Urine was collected daily in 24-h pools for measurement of concentrations of creatinine, calcium, phosphorus, and magnesium.

To determine whether in the affected children the serum concentrations of calcium, phosphorus, and IPTH and the urinary excretion of phosphorus during the day were different from those of normal children, measurements were made during the day in seven of the eight 
children with moderate renal insufficiency (on day 3 of the control period) and in five of the healthy children. The healthy children, also studied at the Pediatric Clinical Research Center, received constant whole food diets that provided $1,000 \mathrm{mg}$ of calcium and $1,200 \mathrm{mg}$ of phosphorus per day for 3-5 d. Meals were offered at 0830, 1215, and 1715 in both groups of subjects. Blood samples were obtained via an indwelling venous catheter before each of the meals, at 30,60, and 120 min after breakfast and lunch, and at 60 and $120 \mathrm{~min}$ after dinner for measurement of serum concentrations of creatinine, calcium, phosphorus, and iPTH. Urine was obtained by voluntary voiding at 2 -h intervals from 0600 to 2000 to measure the concentrations of creatinine and phosphorus. Water intake was encouraged during the study.

\section{Laboratory methods}

Vitamin D metabolite assay. Approximately $2,500 \mathrm{dpm}$ each of chromatographically purified 25 -hydroxy $\left[23,24(\mathrm{n})^{-3} \mathrm{H}\right]$ vitamin $\mathrm{D}_{3}$ and 1,25 dihydroxy $\left[23,24(n){ }^{3} \mathrm{H}\right]$ vitamin $\mathrm{D}_{3}$ (Amersham Corp., Arlington Heights, IL) in $0.02 \mathrm{ml}$ of absolute ethanol were added to each 2-ml plasma sample to determine percentage of recovery. Plasma lipids were extracted twice with diethyl ether $(3: 1, \mathrm{vol} / \mathrm{vol})$, and the extract was chromatographed on a column $(0.7 \times 12 \mathrm{~cm})$ of Sephadex LH-20 developed in hexane/chloroform/methanol $(9: 1: 1)$.

25-OHD. Plasma 25-OHD was quantitated in a manner similar to that described by Eisman et al. (45). The fraction from the LH-20 chromatography that contained 25-OHD was further purified using a Waters Model 6000 high-pressure liquid chromatographic system (Waters Associates, Milford, MA) with two $\mu$-porasil columns in series in a solvent system of hexane/isopropanol (96:4) at a flow rate of 2.0 $\mathrm{ml} / \mathrm{min}$. Quantitation of 25-OHD was accomplished by comparison of the ultraviolet absorbance maximum at $254 \mathrm{~nm}$ of the sample to that of a series of $25-\mathrm{OHD}_{2}$ and $25-\mathrm{OHD}_{3}$ standards. Overall recovery of 25 -hydroxy $\left[23,24(n)-{ }^{3} H\right]$ vitamin $D_{3}$ was $60-65 \%$. The recoveries of $25-\mathrm{OHD}_{2}$ and $25-\mathrm{OHD}_{3}$ were assumed to be the same. In normal adult subjects, the plasma concentration of total 25-OHD $\left(25-\mathrm{OHD}_{2}\right.$ and $25-$ $\mathrm{OHD}_{3}$ ) was $24 \pm 2 \mathrm{ng} / \mathrm{ml}($ mean $\pm \mathrm{SEM}, n=31)$.

$1,25-(\mathrm{OH})_{2} \mathrm{D}$. The fraction from the LH-20 chromatography that contained $1,25-(\mathrm{OH})_{2} \mathrm{D}$ was further purified by high-pressure liquid chromatography using two $\mu$-porasil columns in series in a solvent system of hexane/isopropanol (9:1) at a flow rate of $2.0 \mathrm{ml} / \mathrm{min}$. 1,25-(OH) $)_{2} \mathrm{D}$ was quantitated in duplicate using a competitive protein binding assay modified from those described by Eisman et al. (46) and Shepard et al. (47). Intestinal cytosol binding protein was obtained from normal vitamin D-adequate chicks. Overall recovery of $1,25-(\mathrm{OH})_{2} \mathrm{D}$ was $70-75 \%$. Intraassay and interassay coefficients of variation were 7.7 and $11.6 \%$, respectively. In normal adult subjects, the plasma concentration of $1,25-$ $(\mathrm{OH})_{2} \mathrm{D}$ was $33 \pm 3 \mathrm{pg} / \mathrm{ml}(n=15)$.

Serum concentrations of immunoreactive parathyroid hormone were measured by radioimmunoassay in the laboratory of Dr. Sara Arnaud using two antisera: GP-IM, which has high affinity for the intact hormone and its carboxyl-terminal fragments but low affinity for PTH (1-34), and is referred to hereafter as carboxyl-iPTH (C-iPTH), and $\mathrm{CH}-12 \mathrm{M}$, which has high affinity for the intact hormone, at least a 30-fold lower affinity for PTH (1-34), and no affinity for carboxyl-terminal fragments, which is referred to hereafter as intact-iPTH (48). Serum and urinary concentrations of calcium were measured by atomic absorption spectrophotometry, serum concentrations of phosphorus by a modification of the Fiske-Subbarow method (49), and urinary phosphorus by autoanalyzer.

Data are presented as group means \pm SEM. The $t$ test for paired data was used to compare differences between values obtained in subjects studied during control intake and either low or high intakes of phosphorus. Where the differences observed were not normally distributed, the data were analyzed by means of the Wilcoxon signed rank test. The unpaired $t$ test was used for all other group comparisons. Correlation coefficients were calculated by Spearman's rank correlation procedure.

\section{Results}

Control conditions. In the eight children with moderate renal insufficiency, the mean plasma concentration of $1,25-(\mathrm{OH})_{2} \mathrm{D}$ was significantly lower than the value in age-matched healthy children $(27 \pm 3$ vs. $36 \pm 2 \mathrm{pg} / \mathrm{ml}, P<0.01)$ (Table I) when the dietary intake of phosphorus in each child was normal. Such a moderate decrease in circulating level of $1,25-(\mathrm{OH})_{2} \mathrm{D}$ appears to be characteristic of children with moderate renal insufficiency, i.e., GFR of $18-48(20)$ or $25-50(21,22) \mathrm{ml} / \mathrm{min}$ per $1.73 \mathrm{M}^{2}$. The plasma concentrations of $25-\mathrm{OHD}$ in the patients and the

Table I. Metabolic and Physiologic Characteristics of Children with Moderate Renal Insufficiency Receiving a Normal Dietary Intake of Phosphorus

\begin{tabular}{lcc}
\hline & $\begin{array}{c}\text { Normal } \\
\text { controls }\end{array}$ & $\begin{array}{c}\text { Moderate renal } \\
\text { insufficiency }\end{array}$ \\
\hline Blood & $(17)^{*}$ & $(8)^{*}$ \\
$1,25-(\mathrm{OH})_{2} \mathrm{D}(\mathrm{pg} / \mathrm{ml})$ & $36 \pm 2$ & $27 \pm 3 \ddagger$ \\
$25-\mathrm{OHD}(\mathrm{ng} / \mathrm{ml})$ & $22 \pm 3$ & $21 \pm 3$ \\
Carboxyl-iPTH $(\mu l e q / \mathrm{ml})$ & $17 \pm 3$ & $66 \pm 10 \S$ \\
Intact-iPTH $(\mathrm{pg} / \mathrm{ml})$ & $119 \pm 8$ & $200 \pm 17 \S$ \\
Calcium $($ total $)(\mathrm{mg} / \mathrm{dl})$ & $10.1 \pm 0.1$ & $9.8 \pm 0.1$ \\
Phosphorus $(\mathrm{mg} / \mathrm{dl})$ & $4.9 \pm 0.1$ & $4.4 \pm 0.2^{\| \prime}$ \\
Ccr (ml/min/1.73 M $\left.{ }^{2}\right)$ & $116 \pm 8$ & $45 \pm 4 \S$ \\
FEPi $(\%)$ & $11.0 \pm 1.3$ & $30.0 \pm 2.6 \S$ \\
& & \\
Urine & $17.9 \pm 1.8$ & $17.9 \pm 2.6$ \\
Phosphorus $(\mathrm{mg} / \mathrm{kg} / 24 \mathrm{~h})$ & $2.8 \pm 1.1$ & $0.7 \pm 0.2^{\| \prime}$ \\
Calcium $(\mathrm{mg} / \mathrm{kg} / 24 \mathrm{~h})$ & $3.6 \pm 0.4$ & $2.8 \pm 0.3$ \\
Magnesium $(\mathrm{mg} / \mathrm{kg} / 24 \mathrm{~h})$ & & \\
& &
\end{tabular}

Data are means \pm SEM. Ccr, creatinine clearance.

* Number of subjects studied. Values for blood concentrations in normal controls were measured in $\mathbf{1 7}$ healthy children. Values for $\mathrm{Ccr}, \mathrm{FEPi}$, and urinary excretions in controls were calculated from measurements made in the five healthy children studied at the Pediatric Clinical Research Center. All mean values given for the eight children with moderate renal insufficiency were calculated from values measured during the control period when dietary phosphorus was normal. For the five children who were studied twice (phosphorus restriction and supplementation), the values used in the calculation of the mean value were those measured during the control period of their first study, which in each child was a study of phosphorus restriction.

$¥$ Value vs. normal control value, $P<0.01$.

$\S P<0.001$.

" $P<0.05$. 
healthy children did not differ significantly. In the children with moderate renal insufficiency, the mean serum concentrations of both C- and intact-iPTH were significantly increased. In both the patients and in the normal children, the serum concentration of phosphorus reached a nadir in the late morning hours and then progressively increased during the early afternoon (Fig. 1). This diurnal pattern is similar to that observed in healthy adult subjects who ingested normal diets (50). In the morning, before breakfast, the mean serum concentration of phosphorus in the patients was significantly lower than that in the five healthy children $(4.9 \pm 0.3$ vs. $5.4 \pm 0.3 \mathrm{mg} / \mathrm{dl}, P<0.05)$; thereafter, the values in the two groups did not differ significantly. The serum concentration of calcium changed little during the daytime, and the values in the two groups of subjects did not differ significantly. The serum concentration of C-iPTH did not change significantly in the post-prandial period in either the patients or the controls.


Figure 1. Serum concentrations of calcium, C-iPTH, and phosphorus, and FEPi during the daytime in seven children with moderate renal insufficiency and in five healthy children. Studies were performed after both groups of subjects had received constant whole food diets providing $1,000 \mathrm{mg}$ of calcium and $1,200 \mathrm{mg}$ of phosphorus per day for $2 \mathrm{~d}$. On the day of the study, meals (closed bars) were offered at 0830,1215 and 1715 . The bracketed points depict mean values $\pm \mathrm{SE}$.
Table II. Metabolic and Physiologic Changes Induced by Restriction and Supplementation of Dietary Phosphorus in Children with Moderate Renal Insufficiency

\begin{tabular}{|c|c|c|}
\hline & $\begin{array}{l}\text { Phosphorus } \\
\text { restriction }(7)^{*}\end{array}$ & $\begin{array}{l}\text { Phosphorus } \\
\text { supplementation (6) }\end{array}$ \\
\hline & \multicolumn{2}{|c|}{ Change from control value } \\
\hline \multicolumn{3}{|l|}{ Blood } \\
\hline $1,25-(\mathrm{OH})_{2} \mathrm{D}(\mathrm{pg} / \mathrm{ml})$ & $+16 \pm 3 \ddagger$ & $-10 \pm 2 \S$ \\
\hline 25-OHD $(n g / m l)$ & $-1 \pm 1$ & $-3 \pm 1$ \\
\hline Carboxyl-iPTH $(\mu l e q / m l)$ & $-19 \pm 6^{\prime \prime}$ & $+73 \pm 35^{\| \pi}$ \\
\hline Intact-iPTH $(p g / m l)$ & $-51 \pm 11 \S$ & $+97 \pm 40^{\| \pi}$ \\
\hline Calcium (total) $(m g / d l)$ & $-0.1 \pm 0.1$ & $-0.2 \pm 0.2$ \\
\hline Phosphorus $(m g / d l)$ & $-0.2 \pm 0.1$ & $+0.4 \pm 0.3$ \\
\hline Magnesium $(m g / d l)$ & $-0.2 \pm 0.1^{\| \prime}$ & $-0.1 \pm 0.1$ \\
\hline $\operatorname{Ccr}\left(\mathrm{ml} / \mathrm{min} / 1.73 \mathrm{M}^{2}\right)$ & 0 & $2 \pm 2$ \\
\hline FEPi (\%) & $-21.4 \pm 2.4^{* *}$ & $+25.3 \pm 3.4^{* *}$ \\
\hline \multicolumn{3}{|l|}{ Urine } \\
\hline Phosphorus (mg/kg/24 h) & $-12.0 \pm 2.5 \ddagger$ & $+21.6 \pm 4.3 \ddagger$ \\
\hline Calcium (mg/kg/24 h) & $+0.6 \pm 0.2 \S$ & 0 \\
\hline Magnesium $(\mathrm{mg} / \mathrm{kg} / 24 \mathrm{~h})$ & $-0.1 \pm 0.4$ & $-0.3 \pm 0.3$ \\
\hline
\end{tabular}

Subjects received constant whole food diets providing $1,000 \mathrm{mg}$ of calcium and $1,200 \mathrm{mg}$ of phosphorus per day for $3 \mathrm{~d}$. The intake of phosphorus was then either restricted $(350 \mathrm{mg} / \mathrm{d}$ coupled with administration of aluminum hydroxide) or supplemented (control diet plus oral administration of $1,200 \mathrm{mg}$ phosphorus as Fleet's Phosphasoda) for $5 \mathrm{~d}$. The intake of calcium was maintained constant. Data are expressed as the mean \pm SEM change from control values.

* Number of subjects studied.

‡ Significant change from control value, $P<0.005$.

$\S P<0.01$.

" $P<0.05$.

I Because the changes induced in iPTH were not normally distributed, the data were analyzed using the Wilcoxon signed rank test. ** $P<0.001$.

The fractional renal excretion of phosphorus $\left(\mathrm{FEP}_{\mathrm{i}}\right)$ during the daytime was significantly higher in the patients than in the normal controls (Fig. 1), as was the $24-\mathrm{h}$ FEP $_{\mathrm{i}}(28 \pm 2$ vs. $11 \pm 1 \%$, $P<0.001$ ) (Table I).

Phosphorus restriction. When the dietary intake of phosphorus was restricted for five days in seven children with moderate renal insufficiency, the plasma concentration of 1,25 $(\mathrm{OH})_{2} \mathrm{D}$ increased in each patient from a mean of $26 \pm 3$ to $42 \pm 2$ $\mathrm{pg} / \mathrm{ml}(60 \pm 11 \%, P<0.005)$, the latter value being slightly (though not significantly) higher than that in the healthy children who ingested normal amounts of phosphorus (Table II, Fig. 2). Plasma concentrations of 25-OHD did not change significantly. The serum concentration of C-iPTH decreased in six of the seven patients; the mean decrease was $19 \pm 6 \mu \mathrm{leq} / \mathrm{ml}(25 \pm 6 \%$, $P<0.05)$. The serum concentration of intact-iPTH decreased 


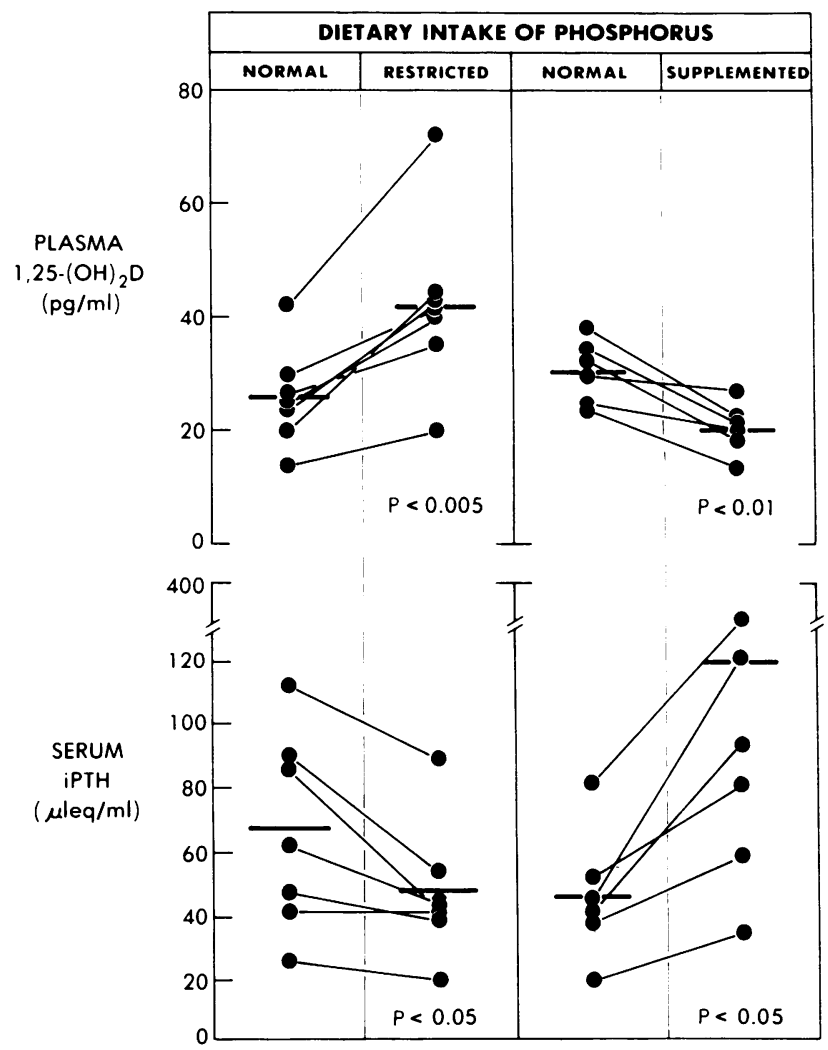

Figure 2. Effect of $5 \mathrm{~d}$ of restriction and of supplementation of dietary phosphorus on the plasma concentration of $1,25-(\mathrm{OH})_{2} \mathrm{D}$ and the serum concentration of C-iPTH in children with moderate renal insufficiency. The dietary intake of phosphorus was normal for $3 \mathrm{~d}$ and then either restricted or supplemented for $5 \mathrm{~d}$. The horizontal bars depict means.

in each of the five patients in whom the measurement was made to a mean value not significantly different from that in the controls; the mean decrease was $51 \pm 11 \mathrm{pg} / \mathrm{ml}(25 \pm 3 \%, P<0.01)$ (Table II). The mean fasting serum concentrations of calcium and phosphorus did not change significantly during the period of phosphorus restriction; the serum concentration of magnesium decreased. Both the 24-h total and fractional urinary excretions of phosphorus decreased rapidly and progressively during the period of phosphorus restriction. After $2 \mathrm{~d}$ of restriction, both values had decreased by $\sim 55 \%$ of the control values; after $5 \mathrm{~d}$ of restriction, total and fractional excretions of phosphorus had decreased by 75 and $71 \%$ of the control values, respectively (Table II). The total urinary excretion of calcium increased significantly within $3 \mathrm{~d}$ of the restriction of phosphorus intake. Urinary excretion of magnesium did not change significantly in the four patients in whom the measurement was made.

Phosphorus supplementation. When the dietary intake of phosphorus was supplemented for $5 \mathrm{~d}$, the plasma concentration of $1,25-(\mathrm{OH})_{2} \mathrm{D}$ decreased in five of the six patients studied from a mean of $30 \pm 2$ to $20 \pm 2 \mathrm{pg} / \mathrm{ml}(32 \pm 7 \%, P<0.01)$ (Table II,
Fig. 2) ${ }^{2}$. Plasma concentrations of $25-\mathrm{OHD}$ did not change significantly. The serum concentrations of both carboxyl- and intact-iPTH increased in each of the patients; the mean increase for C-iPTH was $73 \pm 35 \mu \mathrm{leq} / \mathrm{ml}(131 \pm 39 \%)$ and for intact-iPTH $97 \pm 40 \mathrm{pg} / \mathrm{ml}(45 \pm 17 \%)(P<0.05$, respectively, by the Wilcoxon signed rank test). After phosphorus had been supplemented for $2 \mathrm{~d}$, the fasting serum concentration of phosphorus increased by a mean of $1.0 \pm 0.5 \mathrm{mg} / \mathrm{dl}$; thereafter it decreased, so that after $5 \mathrm{~d}$ of supplementation the mean value was not significantly different from that during the control period (Table II). The mean serum concentrations of calcium and magnesium did not change significantly during the period of phosphorus supplementation. Both the 24-h total and fractional urinary excretions of phosphorus increased progressively during phosphorus supplementation, and the increase for both was significant after $1 \mathrm{~d}$ of supplementation. Total urinary excretions of calcium and magnesium did not change significantly.

When the results obtained with high and low dietary intakes of phosphorus were analyzed as a single set, the changes induced in the plasma concentration of $1,25-(\mathrm{OH})_{2} \mathrm{D}$ correlated significantly and inversely with the changes induced in serum concentrations of both carboxyl- and intact-iPTH $(r=-0.88$, $P<0.001$, Fig. 3). The changes induced in the concentration of $1,25-(\mathrm{OH})_{2} \mathrm{D}$ did not correlate with changes in serum concentrations of calcium, phosphorus, or magnesium, or with changes in total and fractional urinary excretions of phosphorus. The value of endogenous creatinine clearance was not affected by changes in phosphorus intake in any study of any patient (Table II).

\section{Discussion}

The present study confirms that in children with moderate renal insufficiency in whom dietary intake of phosphorus is not restricted, the mean plasma concentration of $1,25-(\mathrm{OH})_{2} \mathrm{D}$ is significantly lower than that observed in age-matched controls (20-22), and the serum concentration of iPTH is increased (21, $22,37)$. In adult patients with chronic renal insufficiency in whom GFR is below $40-50 \mathrm{ml} / \mathrm{min}$, circulating levels of $1,25-(\mathrm{OH})_{2} \mathrm{D}$ have been found to be decreased and to vary in direct proportion with estimated GFR $(17-19,23,24)$. In those adults in whom GFR is $\sim 50 \mathrm{ml} / \mathrm{min}$ or greater, the values of $1,25-(\mathrm{OH})_{2} \mathrm{D}$ are normal or even increased $(15,23)$. In the present study, the observed increase in C-iPTH may reflect in part re-

2. When their phosphorus supplementation studies were performed, 1 and $2 \mathrm{yr}$, respectively, after their phosphorus restriction studies, two of the five twice-studied patients had become pubescent and were undergoing a somatic growth "spurt". In these two patients the control values of plasma $1,25-(\mathrm{OH})_{2} \mathrm{D}$ (when dietary phosphorus was normal) had increased by 10 and $13 \mathrm{pg} / \mathrm{ml}$, respectively. The higher values attained accounted for a mean control value of $1,25-(\mathrm{OH})_{2} \mathrm{D}$ that was $4 \mathrm{pg} / \mathrm{ml}$ higher in the supplementation study than in the restriction study. In healthy children, the plasma concentration of $1,25-(\mathrm{OH})_{2} \mathrm{D}$ increased strikingly during puberty coincident with the peak in growth velocity $(50 a)$. 


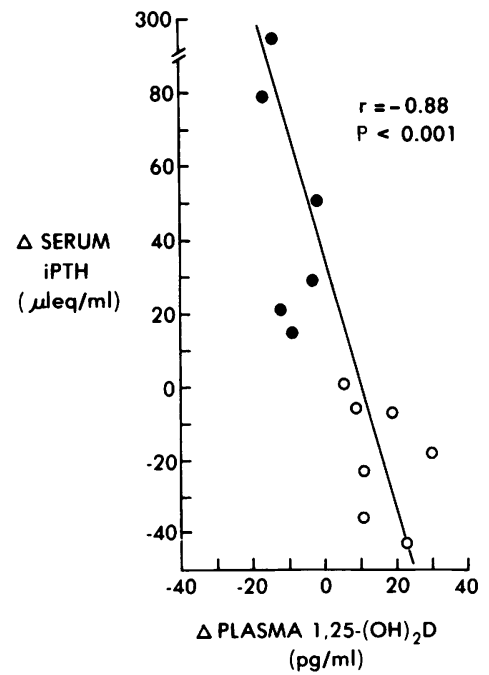

duced renal clearance of biologically inactive fragments of PTH (51), whereas the increase in intact-iPTH presumably reflects an increase in biologically active hormone (48). In confirming that restriction of dietary phosphorus can reverse the hyperparathyroidism of patients with moderate renal insufficiency (52), the observations made in the present study, like those made previously in the dog with experimental reduction of renal mass $(27,53-55)$, provide further support for the formulation that a normal dietary intake of phosphorus can pathogenetically determine the hyperparathyroidism characteristic of chronic renal insufficiency $(27,53-55)$.

In patients with moderate renal insufficiency, restriction of dietary phosphorus might prevent or ameliorate secondary hyperparathyroidism by preventing an otherwise predictable if transient increase in the serum concentration of phosphorus that increases the release of PTH by reciprocally decreasing the plasma concentration of ionized calcium (56). In such patients, the repeatedly observed and currently confirmed decrease in the morning fasting serum concentration of phosphorus $(21$, $36,57,58$ ) might be a consequence of hyperparathyroidism; which is evoked and possibly amplified by earlier postprandial hyperphosphatemia (59). But in the present study, when the dietary intake of phosphorus was normal in the children with moderate renal insufficiency, the serum concentration of phosphorus was not higher than that of normal control subjects at any time during the day, and the serum concentration of $\mathrm{iPTH}$ did not increase after meals in either group of subjects (Fig. 1). Thus, it would be difficult to infer that in the children with moderate renal insufficiency, the extant hyperparathyroidism is either caused by transient increases in the serum concentration of phosphorus or reversed by prevention of such increases.

The present study demonstrates, however, that in the children with moderate renal insufficiency, restriction of dietary phosphorus for $5 \mathrm{~d}$ not only decreased the serum concentration of intact-iPTH (and C-iPTH) but also increased the mean plasma concentration of $1,25-(\mathrm{OH})_{2} \mathrm{D}$ by $60 \%$, the concentrations of both hormones changing to values not significantly different from those of the normal children. Conversely, when dietary phosphorus was supplemented for $5 \mathrm{~d}$, the concentrations of iPTH increased further, and those of $1,25-(\mathrm{OH})_{2} \mathrm{D}$ decreased further by $32 \%$. When dietary phosphorus was restricted or supplemented, the mean plasma concentration of $1,25-(\mathrm{OH})_{2} \mathrm{D}$ ranged from 42 to $20 \mathrm{pg} / \mathrm{ml}$, respectively; the mean serum concentration of C-iPTH ranged from 48 to $119 \mu \mathrm{leq} / \mathrm{ml}$ and that of intact-iPTH from 147 to $297 \mathrm{pg} / \mathrm{ml}$, respectively. These data demonstrate that in children with moderate renal insufficiency, dietary intake of phosphorus is a major determinant of the circulating concentrations of both $1,25-(\mathrm{OH})_{2} \mathrm{D}$ and $\mathrm{PTH}$, which vary inversely and directly, respectively, with the intake of phosphorus, and increase and decrease, respectively, to normal values when phosphorus is restricted for $5 \mathrm{~d}$.

Thus, with both restriction and supplementation of dietary phosphorus, the circulating concentrations of iPTH vary inversely with those of $1,25-(\mathrm{OH})_{2} \mathrm{D}$. When the hormonal changes induced in each of the 13 studies are analyzed as a single set, the changes induced in the circulating concentrations of iPTH correlated strongly, but inversely, with those induced in $1,25-(\mathrm{OH})_{2} \mathrm{D}(r=-0.88, P<0.001$, Fig. 3$)$. If the phosphorusinduced changes in circulating iPTH were primary and mediating of changes in the level of $1,25-(\mathrm{OH})_{2} \mathrm{D}$, one would expect the relationship between these changes to be direct, not inverse. Under normal circumstances, PTH stimulates 1-hydroxylase $(31-33)$ and the production of $1,25-(\mathrm{OH})_{2} \mathrm{D}(60)$. In subjects with intact renal function, increased circulating levels of iPTH are predictably attended by increased levels of $1,25-(\mathrm{OH})_{2} \mathrm{D}(14$, 61-63), and in patients with primary hyperparathyroidism, the plasma concentration of $1,25-(\mathrm{OH})_{2} \mathrm{D}$ decreased abruptly from greatly increased values to normal values when parathyroid adenomas were surgically removed (64). In normal adult subjects in whom dietary calcium was either restricted or supplemented, the changes induced in the circulating concentration of iPTH correlated directly with those induced in the concentration of $1,25-(\mathrm{OH})_{2} \mathrm{D}(65)$.

We would propose that in the currently studied children with moderate renal insufficiency, manipulation of dietary phosphorus induced changes in the plasma concentration of $1,25-(\mathrm{OH})_{2} \mathrm{D}$ that were primary and mediating of, at least in part, the changes observed in the serum concentration of iPTH. Specifically, by increasing the plasma concentration of $1,25-(\mathrm{OH})_{2} \mathrm{D}$, phosphorus restriction could have induced an increase in the plasma concentration of ionized calcium by increasing both its intestinal absorption and bone resorption, and thereby could have decreased the release and hence the serum concentration of iPTH. Conversely, by further decreasing the plasma concentration of $1,25-(\mathrm{OH})_{2} \mathrm{D}$, phosphorus supplementation could have induced the further increase in serum concentration of iPTH. Although plasma-ionized calcium was not measured in the present study, the phosphorus-induced changes in plasma concentration of $1,25-(\mathrm{OH})_{2} \mathrm{D}$ occurred over 
a range of values found to correlate directly with intestinal absorption of calcium $(19,61)$. When hypercalciuria was induced in healthy adult subjects by sodium loading, a $34 \%$ increase in serum concentration of $1,25-(\mathrm{OH})_{2} \mathrm{D}$ was attended by a significant increase in intestinal absorption of calcium (66). That the $60 \%$ increase in circulating $1,25-(\mathrm{OH})_{2} \mathrm{D}$ induced in the present study could have increased intestinal absorption of calcium within $5 \mathrm{~d}$ is supported by two observations in normal adult subjects: intestinal absorption of calcium $\left({ }^{47} \mathrm{Ca}\right)$ increased significantly when first measured 6-8 d after initiation of presumably physiologic amounts of $1,25-(\mathrm{OH})_{2} \mathrm{D}_{3}(0.14 \mu \mathrm{g} / \mathrm{d}$, per os) (67); and, urinary excretion of calcium increased significantly and to a plateau by the 2 nd-5th $d$ of administration of 1,25 $(\mathrm{OH})_{2} \mathrm{D}_{3}$ in somewhat greater amounts $(0.68 \mu \mathrm{g} / \mathrm{d})$, suggesting that the maximal effect of this hormone had been realized in this period (68).

The hyperparathyroidism of patients with chronic renal insufficiency may reflect, in part, disordered regulation of secretion of PTH by the plasma concentration of ionized calcium (69, 70). Although it is unclear whether $1,25-(\mathrm{OH})_{2} \mathrm{D}$ per se can suppress the release of $\mathrm{PTH}$, the increase in plasma concentration of $1,25-(\mathrm{OH})_{2} \mathrm{D}$ induced in the present studies by phosphorus restriction may have rendered the parathyroid glands more susceptible to suppression by plasma-ionized calcium $(71,72)$. If so, the suppressive effect of an even minimal increase in plasmaionized calcium, one that need not be reflected by an increase in the concentration of total calcium, could be amplified by the observed increase in plasma concentration of $1,25-(\mathrm{OH})_{2} \mathrm{D}$. Whatever the precise mediating mechanisms, the results of the present study provide support for the hypothesis that in children with moderate renal insufficiency, a normal dietary intake of phosphorus, which is not associated with an increase in serum concentration of phosphorus, entrains a decrease in the plasma concentration of $1,25-(\mathrm{OH})_{2} \mathrm{D}$ that contributes to the pathogenesis of the hyperparathyroidism characteristic of these patients.

In dogs with experimental chronic renal insufficiency, Kaplan et al. (55) observed that restriction of dietary phosphorus in proportion to the reduction in GFR was attended within $2 \mathrm{~d}$ not only by reversal of secondary hyperparathyroidism but also by an increase in the plasma concentration of ionized calcium from a normal to a supernormal level. Over the subsequent 2 wk, the serum concentration of iPTH continued to decrease, while that of ionized calcium remained increased. The serum concentration of phosphorus remained normal and unchanged after phosphorus restriction. The investigators suggested that phosphorus restriction could have caused the persisting hypercalcemia by stimulating the kidney to increase the synthesis and plasma level of $1,25-(\mathrm{OH})_{2} \mathrm{D}$, and thereby could have increased the intestinal absorption of calcium; they reported no measurements of plasma $1,25-(\mathrm{OH})_{2} \mathrm{D}$. In a preliminary report of adult patients with early renal failure (GFR of $46-70 \mathrm{ml}$ / $\mathrm{min}$ ), Llach et al. (30) indicated that restriction of dietary phosphorus for $\mathbf{4 5} \mathrm{d}$ was attended by reversal of hyperparathyroidism, an increase in both intestinal absorption of calcium and calcemic response to parathyroid extract, and an improvement in bone histology, even though the serum concentration of phosphorus did not change. These investigators too suggested that an increase in plasma concentration of $1,25-(\mathrm{OH})_{2} \mathrm{D}$ might have mediated the changes induced by phosphorus restriction.

Phosphorus is known to be an important determinant of the renal synthesis of $1,25-(\mathrm{OH})_{2} \mathrm{D}$ and thereby of its plasma concentration. In parathyroidectomized, vitamin D-deficient chicks and rats, the activity of 1-hydroxylase (33) and the apparent production of $1,25-(\mathrm{OH})_{2} \mathrm{D}(73)$ varies inversely with the serum concentration of phosphorus. In the intact chick, phosphorus restriction stimulates the activity of 1-hydroxylase (39), and in the intact rat it increases both the plasma concentration $(38,42)$ and the renal synthesis $(74)$ of $1,25-(\mathrm{OH})_{2} \mathrm{D}$. In healthy women, phosphorus restriction induced a $45 \%$ increase in the circulating concentration of $1,25-(\mathrm{OH})_{2} \mathrm{D}$ despite a decrease in the concentration of $\mathrm{IPTH}(41)$, and in healthy men it induced an increase in both the serum concentration of $1,25-(\mathrm{OH})_{2} \mathrm{D}$ and in its rate of production (75). In patients with either idiopathic hypercalciuria (43) or primary hyperparathyroidism (44), supplementation of dietary phosphorus decreased the circulating concentration of $1,25-(\mathrm{OH})_{2} \mathrm{D}$ despite a significant increase in the concentration of iPTH and no increase in the serum concentration of phosphorus. One group of investigators speculated that the increased intake of phosphorus altered renal synthesis of $1,25-(\mathrm{OH})_{2} \mathrm{D}$ by altering either the transcellular flux of phosphorus or its concentration in the renal cell (43). Indeed, it has been proposed that renal synthesis of $1,25-(\mathrm{OH})_{2} \mathrm{D}$ is principally determined by the concentration of inorganic phosphorus in renal cortical cells (73).

The proximal renal tubule is the principal site of both the renal reabsorption of phosphorus (76-78) and the activity of 1-hydroxylase (9-11). In the currently studied children with moderate renal insufficiency, a normal dietary intake of phosphorus was attended by a greatly increased fractional excretion of phosphorus, which reflected an increased rate of phosphorus excretion per nephron, and presumably an increased delivery of phosphorus to more distal segments of the remaining proximal tubules. An increase in intracellular concentration or transepithelial processing of phosphorus in the proximal tubule might suppress the activity of 1-hydroxylase, and thereby restrict the synthesis of $1,25-(\mathrm{OH})_{2} \mathrm{D}$, even in the absence of an increased serum level of phosphorus and despite the presence of an increased serum level of iPTH. When the children with moderate renal insufficiency were phosphorus restricted for only $5 \mathrm{~d}$, fractional excretion of phosphorus decreased from 31 to $9 \%$, a value like that found in normal children receiving a normal dietary intake of phosphorus. Thus, in the affected children, even shortterm dietary restriction of phosphorus could increase the activity of 1-hydroxylase and production rate of $1,25-(\mathrm{OH})_{2} \mathrm{D}$ to normal values, through a mechanism that depends upon a reduction in the rate of phosphorus excretion per nephron to normal values. 


\section{Acknowledgments}

We gratefully acknowledge helpful discussions with Ralph Goldsmith and Sara Arnaud. We thank the nursing staff of the Pediatric Clinical Research Center. We also thank Bernadine Serena, Vivian Ho, Marilyn Levens, and Teresa Serata for technical assistance, and Kathleen Peterson, Carol McAnnally, and Alcyne Wong for help in preparation of this manuscript.

This work was supported by grants from the National Institutes of Health (National Institute of Arthritis, Metabolism and Digestive Diseases, Nos. AM 21354 and AM 27112), the Division of Research Resources (General Clinical Research Center, No. RR 00079), from the Veterans Administration, and by generous gifts from the Church and Dwight Corporation and the Emil Mosbacher, Jr. Foundation.

\section{References}

1. Holick, M. F., M. Garabedian, and H. F. DeLuca. 1972. 1,25Dihydroxycholecalciferol: metabolite of vitamin $D_{3}$ active on bone in anephric rats. Science (Wash. DC). 176:1146-1147.

2. Boyle, I. T., L. Miravet, R. W. Gray, M. F. Holick, and H. F. DeLuca. 1972. The response of intestinal calcium transport to 25-hydroxy and 1,25-dihydroxyvitamin D in nephrectomized rats. Endocrinology. 90:605-608.

3. Norman, A. W., and R. G. Wong. 1972. Biological activity of the vitamin D metabolite 1,25-dihydroxycholecalciferol in chickens and rats. J. Nutr. 102:1709-1718.

4. Chen, T. C., L. Castillo, M. Korycka-Dahl, and H. F. DeLuca. 1974. Role of vitamin D. metabolites in phosphate transport of rat intestine. J. Nutr. 104:1056-1060.

5. Fraser, D. R., and E. Kodicek. 1970. Unique biosynthesis by kidney of biologically active vitamin D metabolite. Nature (Lond.). 228:764-766.

6. Gray, R. W., I. Boyle, and H. F. DeLuca. 1971. Vitamin D metabolism: the role of kidney tissue. Science (Wash. DC). 172:12321234.

7. Gray, R. W., J. L. Omdahl, J. G. Ghazarian, and H. F. DeLuca. 1972. 25-Hydroxycholecalciferol-1-hydroxylase. Subcellular location and properties. J. Biol. Chem. 247:7528-7532.

8. Midgett, R. J., A. M. Speilvogel, J. W. Coburn, and A. W. Norman. 1973. Studies on calciferol metabolism. VI. The renal production of the biologically active form of vitamin D, 1,25-dihydroxycholecalciferol. $J$. Clin. Endocrinol. Metab. 36:1153-1161.

9. Brunette, M. B., M. Chan, C. Ferriere, and K. D. Roberts. 1978. Site of $1,25-(\mathrm{OH})_{2}$ vitamin $\mathrm{D}_{3}$ synthesis in the kidney. Nature (Lond.). 276:287-289.

10. Akiba, T., H. Endou, C. Koseki, F. Sakai, N. Horiuchi, and T. Suda. 1980. Localization of 25 -hydroxyvitamin $D_{3}-1 \alpha$-hydroxylase activity in the mammalian kidney. Biochem. Biophys. Res. Commun. 94:313-318.

11. Kawashima, H., S. Torikai, and K. Kurokawa. 1981. Localization of 25-hydroxyvitamin $D_{3} 1 \alpha$-hydroxylase and 24-hydroxylase along the rat nephron. Proc. Natl. Acad. Sci. USA. 78:1199-1203.

12. Brumbaugh, P. F., D. H. Haussler, R. Bressler, and M. R. Haussler. 1974. Radioreceptor assay for $1 \alpha, 25$-dihydroxyvitamin $D_{3}$. Science (Wash. DC). 183:1089-1091.

13. Eisman, J. A., A. J. Hamstra, B. E. Kream, and H. F. DeLuca. 1976. 1,25-Dihydroxyvitamin D in biological fluids: a simplified and sensitive assay. Science (Wash. DC). 193:1021-1023.

14. Haussler, M. R., D. J. Baylink, M. R. Hughes, P. F. Brumbaugh,
J. E. Wergedal, F. H. Shen, R. L. Nielsen, S. J. Counts, K. M. Bursac, and T. A. McCain. 1976. The assay of $1 \alpha, 25$-dihydroxyvitamin $\mathrm{D}_{3}$ : physiologic and pathologic modulation of circulating hormone levels. Clin. Endocrinol. 5(Suppl.):151s-165s.

15. Slatopolsky, E., R. Gray, N. D. Adams, J. Lewis, K. Hruska, K. Martin, S. Klahr, H. De Luca, and J. Lemann. 1978. Low serum levels of $1,25-(\mathrm{OH})_{2} \mathrm{D}$ are not responsible for the development of secondary hyperparathyroidism in early renal failure. Kidney Int. 14:733. (Abstr.)

16. Chesney, R. W., J. F. Rosen, A. J. Hamstra, and H. F. DeLuca. 1980. Serum 1,25-dihydroxyvitamin $D$ levels in normal children and in vitamin D disorders. Am. J. Dis. Child. 134:135-139.

17. Mason, R. S., D. Lissner, M. Wilkinson, and S. Posen. 1980 Vitamin D metabolites and their relationship to azotaemic osteodystrophy. Clin. Endocrinol. 13:375-385.

18. Christiansen, C., M. S. Christensen, F. Melsen, P. Rodbro, and H. F. DeLuca. 1981. Mineral metabolism in chronic renal failure with special reference to serum concentrations of $1,25(\mathrm{OH})_{2} \mathrm{D}$ and 24,25(OH) 2 D. Clin. Nephrol. 15:18-22.

19. Juttmann, J. R., C. J. Buurman, E. De Kam, T. J. Visser, and J. C. Birkenhager. 1981. Serum concentrations of metabolites of vitamin $\mathrm{D}$ in patients with chronic renal failure (CRF). Consequences for the treatment with 1- $\alpha$-hydroxy-derivatives. Clin. Endocrinol. 14:225-236.

20. Chesney, R. W., A. J. Hamstra, R. B. Mazess, P. Rose, and H. F. DeLuca. 1982. Circulating vitamin D metabolite concentrations in childhood renal diseases. Kidney Int. 21:65-69.

21. Portale, A. A., B. E. Booth, H. C. Tsai, and R. C. Morris, Jr. 1982. Reduced plasma concentration of 1,25-dihydroxyvitamin D in children with moderate renal insufficiency. Kidney Int. 21:627-632.

22. Taylor, A., and M. E. Norman. 1982. Interrelationships of serum 25-hydroxyvitamin $\mathrm{D}_{3}$ and 1,25-dihydroxyvitamin $\mathrm{D}$ in juvenile renal osteodystrophy after therapy with 25 -hydroxyvitamin $\mathrm{D}_{3}$. Metab. Bone Dis. Relat. Res. 4:255-261.

23. Cheung, A. K., S. C. Manolagas, B. D. Catherwood, C. A. Mosely, Jr., J. A. Mitas II, R. C. Blantz, and L. J. Deftos. 1983. Determinants of serum 1,25-(OH $)_{2} \mathrm{D}$ levels in renal disease. Kidney Int. 24:104-109.

24. Tessitore, N., B. Lund, B. Lund, O. H. Sorensen, E. Bonucci, and G. Maschio. 1981. Vitamin D metabolites in patients with early renal failure: effects of dietary phosphate restriction and calcium supplementation. Kidney Int. 20:303. (Abstr.)

25. Mawer, E. B., C. M. Taylor, J. Backhouse, G. A. Lumb, and S. W. Stanbury. 1973. Failure of formation of 1,25-dihydroxycholecalciferol in chronic renal insufficiency. Lancet. I:626-628.

26. Piel, C. F., B. S. Roof, and L. V. Avioli. 1973. Metabolism of tritiated 25-hydroxycholecalciferol in chronically uremic children before and after successful renal homotransplantation. J. Clin. Endocrinol. Metab. 37:944-948.

27. Rutherford, W. E., P. Bordier, P. Marie, K. Hruska, H. Harter A. Greenwalt, J. Blondin, J. Haddad, N. Bricker, and E. Slatopolsky. 1977. Phosphate control and 25-hydroxycholecalciferol administration in preventing experimental renal osteodystrophy in the dog. J. Clin. Invest. 60:332-341.

28. Haussler, M. R., and T. A. McCain. 1977. Basic and clinical concepts related to vitamin D metabolism and action. $N$. Engl. J. Med. 297:974-983; 1041-1050.

29. Van Stone, J. C., D. E. Frank, and W. R. Bradford. 1977. The effect of decreased renal function with and without reduction in renal mass on 1,25-dihydroxycholecalciferol production in rats. J. Lab. Clin. Med. 89:1168-1174.

30. Llach, F., S. G. Massry, A. Koffler, H. H. Malluche, F. R. Singer, 
A. S. Brickman, and K. Kurokawa. 1977. Secondary hyperparathyroidism in early renal failure: role of phosphate retention. Clin. Res. 25:507. (Abstr.)

31. Fraser, D. R., and E. Kodicek. 1973. Regulation of 25-hydroxycholecalciferol-1-hydroxylase activity in kidney by parathyroid hormone. Nat. New Biol. 241:163-166.

32. Henry, H. L., R. J. Midgett, and A. W. Norman. 1974. Regulation of 25-hydroxyvitamin $\mathrm{D}_{3}$-1-hydroxylase in vivo. J. Biol. Chem. 249:75847592.

33. Booth, B. E., H. C. Tsai, and R. C. Morris, Jr. 1977. Parathyroidectomy reduces 25 -hydroxyvitamin $\mathrm{D}_{3}-1 \alpha$-hydroxylase activity in the hypocalcemic vitamin D-deficient chick. J. Clin. Invest. 60:13141320.

34. Reiss, E., J. M. Canterbury, and R. H. Egdahl. 1968. Experience with a radioimmunoassay of parathyroid hormone in human sera. Trans. Assoc. Am. Physicians. 81:104-114.

35. Arnaud, C. D. 1973. Hyperparathyroidism and renal failure. Kidney Int. 4:89-95.

36. Llach, F., S. G. Massry, F. R. Singer, K. Kurokawa, J. H. Kaye, and J. W. Coburn. 1975. Skeletal resistance to endogenous parathyroid hormone in patients with early renal failure. A possible cause for secondary hyperparathyroidism. J. Clin. Endocrinol. Metab. 41:339-345.

37. Norman, M. E., A. T. Mazur, S. Borden IV, A. Gruskin, C. Anast, R. Baron, and H. Rasmussen. 1980. Early diagnosis of juvenile renal osteodystrophy. J. Pediatr. 97:226-232.

38. Hughes, M. R., P. F. Brumbaugh, M. R. Haussler, J. E. Wergedal, and D. J. Baylink. 1975. Regulation of serum 1 $\alpha$,25-dihydroxyvitamin $\mathrm{D}_{3}$ by calcium and phosphate in the rat. Science (Wash. DC). 190:578580 .

39. Baxter, L. A., and H. F. DeLuca. 1976. Stimulation of 25 -hydroxyvitamin $\mathrm{D}_{3}-1 \alpha$-hydroxylase by phosphate depletion. J. Biol. Chem. 251:3158-3161.

40. Dominguez, J. H., R. W. Gray, and J. Lemann, Jr. 1976. Dietary phosphate deprivation in women and men: effects on mineral and acid balances, parathyroid hormone and the metabolism of 25-OH-vitamin D. J. Clin. Endocrinol. Metab. 43:1056-1068.

41. Gray, R. W., D. R. Wilz, A. E. Caldas, and J. Lemann, Jr. 1977. The importance of phosphate in regulating plasma $1,25-(\mathrm{OH})_{2}$-vitamin $D$ levels in humans: studies in healthy subjects, in calcium-stone formers and in patients with primary hyperparathyroidism. J. Clin. Endocrinol. Metab. 45:299-306.

42. Rader, J. I., D. J. Baylink, M. R. Hughes, E. F. Safilian, and M. R. Haussler, 1979. Calcium and phosphorus deficiency in rats: effects on PTH and 1,25-dihydroxyvitamin $\mathrm{D}_{3}$. Am. J. Physiol. 236:E118E122.

43. Van den Berg, C. J., R. Kumar, D. M. Wilson, H. Heath III, and L. H. Smith. 1980. Orthophosphate therapy decreases urinary calcium excretion and serum 1,25-dihydroxyvitamin D concentrations in idiopathic hypercalciuria. J. Clin. Endocrinol. Metab. 51:998-1001.

44. Broadus, A. E., J. S. Magee, L. E. Mallette, R. L. Horst, R. Lang, P. S. Jensen, J. M. Gertner, and R. Baron. 1983. A detailed evaluation of oral phosphate therapy in selected patients with primary hyperparathyroidism. J. Clin. Endocrinol. Metab. 56:953-961.

45. Eisman, J. A., R. M. Shepard, and H. F. DeLuca. 1977. Determination of 25-hydroxyvitamin $\mathrm{D}_{2}$ and 25-hydroxyvitamin $\mathrm{D}_{3}$ in human plasma using high-pressure liquid chromatography. Anal. Biochem. 80:298-305.

46. Eisman, J. A., A. J. Hamstra, B. E. Kream, and H. F. DeLuca. 1976. A sensitive, precise, and convenient method for determination of 1,25-dihydroxyvitamin D in human plasma. Arch. Biochem. Biophys. 176:235-243.
47. Shephard, R. M., R. L. Horst, A. J. Hamstra, and H. F. DeLuca. 1979. Determination of vitamin $D$ and its metabolites in plasma from normal and anephric man. Biochem. J. 182:55-69.

48. Gallagher, J. C., B. L. Riggs, C. M. Jerpbak, and C. D. Arnaud. 1980. The effect of age on serum immunoreactive parathyroid hormone in normal and osteoporotic women. J. Lab. Clin. Med. 95:373-385.

49. Fiske, C. H., and Y. Subbarow. 1925. The colorimetric determination of phosphorus. J. Biol. Chem. 66:375-400.

50. Markowitz, M., L. Rotkin, and J. F. Rosen. 1981. Circadian rhythms of blood minerals in humans. Science (Wash. DC). 213:672674.

50a. Aksnes, L., and D. Aarskog. 1982. Plasma concentrations of vitamin D metabolites in puberty: effect of sexual maturation and implications for growth. J. Clin. Endocrinol. Metab. 55:94-101.

51. Freitag, J., K. J. Martin, K. A. Hruska, C. Anderson, M. Conrades, J. Ladenson, S. Klahr, and E. Slatopolsky. 1978. Impaired parathyroid hormone metabolism in patients with chronic renal failure. N. Engl. J. Med. 298:29-32.

52. Fotino, S. 1977. Phosphate excretion in chronic renal failure: evidence for a mechanism other than circulating parathyroid hormone. Clin. Nephrol. 8:499-503.

53. Slatopolsky, E., S. Caglar, J. P. Pennell, D. D. Taggart, J. M. Canterbury, E. Reiss, and N. S. Bricker. 1971. On the pathogenesis of hyperparathyroidism in chronic experimental renal insufficiency in the dog. J. Clin. Invest. 50:492-499.

54. Slatopolsky, E., S. Caglar, L. Gradowska, J. Canterbury, E. Reiss, and N. S. Bricker. 1972. On the prevention of secondary hyperparathyroidism in experimental chronic renal disease using "proportional reduction" of dietary phosphorus intake. Kidney Int. 2:147-151.

55. Kaplan, M. A., J. M. Canterbury, J. J. Bourgoignie, G. Veliz, G. Gavellas, E. Reiss, and N. S. Bricker. 1979. Reversal of hyperparathyroidism in response to dietary phosphorus restriction in the uremic dog. Kidney Int. 15:43-48.

56. Slatopolsky, E., and N. S. Bricker. 1973. The role of phosphorus restriction in the prevention of secondary hyperparathyroidism in chronic renal disease. Kidney Int. 4:141-145.

57. Friis, Th., S. Hahnemann, and E. Weeke. 1968. Serum calcium and serum phosphorus in uraemia during administration of sodium phytate and aluminium hydroxide. Acta Med. Scand. 183:497-505.

58. Coburn, J. W., M. H. Koppel, A. S. Brickman. and S. G. Massry. 1973. Study of intestinal absorption of calcium in patients with renal failure. Kidney Int. 3:264-272.

59. Slatopolsky, E., W. E. Rutherford, K. Hruska, K. Martin, and S. Klahr. 1978. How important is phosphate in the pathogenesis of renal osteodystrophy? Arch. Intern. Med. 138:848-852.

60. Garabedian, M., M. F. Holick, H. F. DeLuca, and I. T. Boyle. 1972. Control of 25-hydroxycholecalciferol metabolism by parathyroid glands. Proc. Natl. Acad. Sci. USA. 69:1673-1676.

61. Kaplan, R. A., M. R. Haussler, L. J. Deftos, H. Bone, and C. Y. C. Pak. 1977 . The role of $1 \alpha, 25$-dihydroxyvitamin D in the mediation of intestinal hyperabsorption of calcium in primary hyperparathyroidism and absorptive hypercalciuria. J. Clin. Invest. 59:756-760.

62. Eisman, J. A., J. D. Wark, R. L. Prince, and J. M. Moseley. 1979. Modulation of plasma, 1,25-dihydroxyvitamin D in man by stimulation and suppression tests. Lancet. II:931-933.

63. Bilezikian, J. P., R. E. Canfield, T. P. Jacobs, J. S. Polay, A. P. D'Adamo, J. A. Eisman, and H. F. DeLuca. 1978. Response of $1 \alpha, 25$ dihydroxyvitamin $\mathrm{D}_{3}$ to hypocalcemia in human subjects. $N$. Engl. J. Med. 299:437-441.

64. Lund, B., O. H. Sorensen, B. Lund, J. E. Bishop, and A. W Norman. 1980. Stimulation of 1,25 -dihydroxyvitamin D production by 
parathyroid hormone and hypocalcemia in man. J. Clin. Endocrinol. Metab. 50:480-483.

65. Adams, N. D., R. W. Gray, and J. Lemann, Jr. 1979. The effects of oral $\mathrm{CaCO}_{3}$ loading and dietary calcium deprivation on plasma 1,25dihydroxyvitamin D concentrations in healthy adults. J. Clin. Endocrinol. Metab. 48:1008-1016.

66. Breslau, N. A., J. L. McGuire, J. E. Zerwekh, and C. Y. C. Pak. 1982. The role of sodium on renal excretion and intestinal absorption of calcium and on vitamin D metabolism. J. Clin. Endocrinol. Metab. 55:369-373.

67. Brickman, A. S., J. W. Coburn, S. G. Massry, and A. W. Norman. 1974. 1,25-dihydroxy-vitamin $D_{3}$ in normal man and patients with renal failure. Ann. Intern. Med. 80:161-168.

68. Brickman, A. S., J. W. Coburn, G. R. Friedman, W. H. Okamura, S. G. Massry, and A. W. Norman. 1976. Comparison of effects of $1 \alpha-$ hydroxy-vitamin $\mathrm{D}_{3}$ and 1,25-dihydroxy-vitamin $\mathrm{D}_{3}$ in man. J. Clin. Invest. 57:1540-1547.

69. Bellorin-Font, E., K. J. Martin, J. J. Freitag, C. Anderson, G. Sicard, E. Slatopolsky, and S. Klahr. 1981. Altered adenylate cyclase kinetics in hyperfunctioning human parathyroid glands. J. Clin. Endocrinol. Metab. 52:499-507.

70. Brown, E. M., R. E. Wilson, R. C. Eastman, J. Pallotta, and S. Marynick. 1982. Abnormal regulation of parathyroid hormone release by calcium in secondary hyperparathyroidism due to chronic renal failure. J. Clin. Endocrinol. Metab. 54:172-179.
71. Oldham, S. B., R. Smith, D. L. Hartenbower, H. L. Henry, A. W. Norman, and J. W. Coburn. 1979. The acute effects of 1,25dihydroxycholecalciferol on serum immunoreactive parathyroid hormone in the dog. Endocrinology. 104:248-254.

72. Madsen, S., K. Olgaard, and J. Ladefoged. 1981. Suppressive effect of 1,25-dihydroxyvitamin $\mathrm{D}_{3}$ on circulating parathyroid hormone in acute renal failure. J. Clin. Endocrinol. Metab. 53:823-827.

73. Tanaka, Y., and H. F. DeLuca. 1973. The control of 25-hydroxyvitamin D metabolism by inorganic phosphorus. Arch. Biochem. Biophys. 154:566-574.

74. Gray, R. W., and J. L. Napoli. 1983. Dietary phosphate deprivation increases 1,25 -dihydroxyvitamin $D_{3}$ synthesis in rat kidney in vitro. J. Biol. Chem. 258:1152-1155.

75. Portale, A. A., B. P. Halloran, M. M. Murphy, and R. C. Morris, Jr. 1984. Dietary phosphorus can determine the serum concentration of $1,25-(\mathrm{OH})_{2} \mathrm{D}$ by determining its production rate in humans. Clin. Res. 32:405. (Abstr.)

76. Strickler, J. C., D. D. Thompson, R. M. Klose, and G. Giebisch. 1964. Micropuncture study of inorganic phosphate excretion in the rat. J. Clin. Invest. 43:1596-1607.

77. Amiel, C., H. Kuntziger, and G. Richet. 1970. Micropuncture study of handling of phosphate by proximal and distal nephron in normal and parathyroidectomized rat. Evidence for distal reabsorption. Pfluegers Arch. Eur. J. Physiol. 317:93-109.

78. Dennis, V. W., W. W. Stead, and J. L. Myers. 1979. Renal handling of phosphate and calcium. Annu. Rev. Physiol. 41:257-271. 